them in reorganising their exhibited collections, and other applications are being considered; to accomplish all this work a permanent office with a paid secretary and staff has been provided.

Other matters on which Sir Henry Miers commented were "the growing magnitude and importance of the Museums Journal" ; the discussion with the Library Association of needed new legislation for public libraries and museums; the federations of museums in Lancashire and Cheshire and in Yorkshire; the reorganisation of various museums in the direction of local education, as at Portsmouth, Salisbury, Port Sunlight, Wisbech, Norwich, and Aylesbury ; and the recent visit of the secretary, Mr. S. F. Markham, M.P., to the United States. More in the future were the suggestions made by the Association to the Standing Commission on Museums; the preparation of a survey of museums throughout the British Empire, and the completion of the directory by a volume including them (this is with the help of the Carnegie Corporation of New York); the growing realisation by the educational departments of the British Government and by tho World Institute of Adult Education of the educational possibilities of museums, long since realised by the Association.

The meeting was noteworthy for the increased time devoted to papers and for the animated discussions. Following the president's address, Dr. W. T. Calman, while approving modern attempts to illustrate the problems of biology, urged that on one hand they should be kept distinct from the systematic series, and on the other that there should be an exhibit definitely explaining the principles and main outlines of taxonomy. Mr. J. Bailey, formerly head of the Circulation Department at the Victoria and Albert Museum, complained that the 1924 and 1931 Loans Acts had not been put into operation, at least so far as the Bloomsbury departments of the British Museum were concerned; his view that the national treasures should be more widely lent out did not find much support from subsequent speakers. An instructive talk on " Plymouth Porcelain", illustrated by the epidiascope, was given by Mr. A. J. Caddie, curator of the Plymouth Museum. "Why do wo use Plate-glass in Museums ?" was the provocative title of Mr. Leney's account of his proposals for an unenclosed reconstruction of the county's natural scene in the Norwich Museum; while sympathising with their colleague's bold and beautiful dream, the practical curators present supplied satisfactory replies to his question.

On Wednesday morning an account of the Courtauld Institute of Art by its director-elect, Mr. W. G. Constable, set at rest doubts that had beon raised by the letters of Lord Lee of Fareham and other notices in the daily press. A fluent and witty speech by $\mathrm{Mr}$. S. C. Kaines Smith, director of the Birmingham Museum, on "Art Museum Problems", provoked much applause and some criticism. After this, "A Suggested System of Museum Registration", by Mr.
K. de B. Codrington, of the Indian Section of the Victoria and Albert Museum, fell a little flat, though it was clearly the fruit of experience and careful thought; there would doubtless have been more discussion had the author not been prevented by illness from attending. The important but somewhat dry subject of paper for museum labels was made interesting by Dr. L. J. Spencer, Keeper of Minerals in the British Museum.

On Thursday, Lieut.-Col. J. M. Mitchell, secretary of the Carnegie United Kingdom Trust, expounded the principles of the Trust's action as laid down by its founder, and thus showed what kind of help museums might expect to receive; this was a revelation to many of those present. Mr. H. J. M. Maltby, of the Salford Museum, showed, perhaps unintentionally, that the "Present-Day Problems of Provincial Museums" are much tho same as the problems that have vexed curators ever since the Association was founded; among them the local town council looms large.

Friday produced three very diverse papers. Mr. J. H. Iliffe, recently professor at the University of Toronto, in charge of classical archæology at the Royal Ontario Museum, spoke on "The Museum Situation in Canada", and urged the importance of personal contact between Canadian curators and their colleagues in the home country, so that the latter might realise the great diversity of outlook and the distinctness of the several regions in the Dominion. Dr. C. Hay Murray, of the Liverpool Museum, re. countod his attempts at estimating the value of the Museum to the public by the length of time spent in the building by visitors; he had found that the average duration of a visit had notably increased of recent years. The final paper, an account by Mr. C. A. Ralegh Radford of the Roman remains discovered at Exeter by excavation, was a valuable contribution to archæology, with no obvious bearing on museum questions.

The only exception that could be taken to the number of papers was that they left little time for visits to museums. Members would gladly have given up the walk round Devonport Dockyard for more opportunity of studying the Plymouth Museum and the recently restored Elizabethan house. They were, however, hospitably and instructively entertained at the Marine Biological Laboratory, and were courteously received at the Athenæum, where is a museum said to be one of the oldest in the country and an excellent example of a learned society's museum in the day of our grandfathers. Too short a stay was made among the delights of Cotehele, visited by kind permission of Lady Mount-Edgcumbe. Other grateful entertainments were a luncheon offered by the Mayor, a Mayoral reception and dance at the Guildhall, and tea at the Abbey Hall on the invitation of Lady Astor, who at the annual dinner proposed health and prosperity to the Museums Association.

\title{
Imperial Sugar Cane Research Conference, I93I.
}

THE first Imporial Sugar Cane Research Conference, which was opened on July 20 by Dr. Drummond Shiels, M.P., is the socond of these conferences of overseas research and administrative men convened by the Empire Marketing Board on a crop rather than on a science basis. The first was the Wool Rescarch Conference held last year. The object is to get a clear picture of research in widely scattered countries, so that the gaps can be clearly seen and a general programme of research for the Empire worked out.

The Board has already made grants for research in
Mauritius, where a Cane Research Station was started last ycar, and in Barbados, and it supports the Imperial College of Tropical Agriculture in Trinidad, where a beginning has been made in fundamental research on cane genetics. Other applications have been received, and the Board decided to consider the broad questions of research policy and of where the work could best be carried out. Besides delegates from home organisations, such as the Imperial Bureau of Plant Genetics at Cambridge (the director of which, Sir Rowland Biffen, attended the Conference), there

No. 3221, VoL. 128] 
were representatives from India, South Africa, Trinidad, Barbados, British Guiana, Fiji, Mauritius, and the Leeward and Windward Islands.

The economic position in each sugar-producing country was outlined, and this was followed by a sketch of the scope and aims of the research stations. Genetics and cane-breeding have hitherto overshadowed the other branches of research, although more attention has lately been given to the control of insect and fungus pests. Interesting details were given of the breeding work at Coimbatore, in South India, where improved varieties of the north Indian hardy cane have been evolved which are estimated to give an increased yield of 50 per cent over the ordinary varieties. Attention is now being given to intergeneric crosses with cereals which aim at reducing the ripening period. One of the Java canes, POJ 2725, has been crossed with Andropogon sorghum and the hybrid has matured in five months, instead of the normal 10-12 months, and yielded a sucrose content of 16 per cent in the juice. Equally remarkable results have been obtained with tropical or 'noble' canes (Saccharum officinarum) in Barbados, where the whole system of cane-breeding first originated. The Department of Science and Agriculture pots out about 16,000 seedlings a year, largely for distribution throughout the West Indies, and one variety in particular, $B H 10(12)$, is now known all over the world.

Each country, however, has its own peculiar requirements, often depending as much on economic as on climatic or edaphic factors, and has to work out its own salvation as regards varieties. But the fundamental aspect has barely been attacked in the Empire, and there is clearly a case for some central station to undertake long-range research admitted to be outside the scope of the ordinary department of agriculture.

\section{University and Educational Intelligence.}

CAmbridge.-The managers of the Frederick James Quick Fund have elected Mr. David Keilin, Magdalone College, to the Quick professorship of biology for a period of three years from Nov. 1, in succession to Dr. G. H. F. Nuttall, Magdalene College, who has held the professorship since 1906, when it was founded.

W. J. Heasman, of Trinity Hall, has been appointed senior curator, and G. J. Kerrich, of Christ's College, junior curator of the Museum of Zoology.

E. E. Pochin, St. John's College, has been elected to the Michael Foster research studentship in physiology.

London.-Prof. C. Burt, part-time professor of education at the London Day Training College, has been appointed professor of psychology in University College, as from Aug. 1, 1932.

The Sir George Jessel studentship in mathematics awarded to Mr. T. E. Garstang, of University College, for 1930-31, has been renewed for the session 1931-32, and a similar studentship awarded to Mr. H. Kestelman, of University College, for the session 1931-32.

Is a note in Nature of July 18, p. 124, in reforring to the reception at the new premises of Messrs. H. K. Lewis and Co., Ltd., it was stated that Prof. Thane discussed text-books; we are informed that the speaker was Prof. H. R. Kenwood, emeritus professor of hygiene in the University of London.

THE following scholarships have been awarded by the Council of the Institution of Naval Architects: Royal Commissioners for the 1851 Exhibition postgraduate research scholarship in naval architecture
(1931), £250 per annum for two years, to Mr. William John Roberts, University of Liverpool ; Sir William White post-graduate scholarship in naval architecture (1931), $£ 150$ per annum for two years, to Dr. J. A. J. Bennett, University of Glasgow.

Sir Camprelt STUart has been appointed chairman of the Beit Fellowships for Scientific Research Trust, and Sir Alfred Beit, a trustee, both in succession to the founder of the fellowships, the late Sir Otto Beit. New fellowships of the value of $£ 250$ a year tenable for two years, beginning September 1931, have been awarded to Mr. W. H. Wheeler (University of Cambridge and the Imperial College) for research on the effects of electric and magnetic fields upon gaseous explosions and detonations and to Mr. J. I. Armstrong (Queen's University, Belfast, and the Imperial College) for research on the respiration of Fungi with special regard to inorganic nutrition.

UNDER the patronage of the New Education Fellowship, a prize of 10,000 francs is being offered for the best treatise on "Total Education (Physically, Intellectually, and Morally)". Realising that the total education of an individual is conditioned chiefly by heredity and environment, the object of the competition is to omphasise the necessity of making inherited qualities the best possible, and of a careful development of such characteristics. Each individual can train himself and others in the world-wide propagation of this education, and it is essential that there should be an understanding between educationists, especially from the universal point of view. Further particulars concerning this prize competition can be obtained from either Groupe Français d'Éducation Nouvelle, 41, Rue Gay-Lussac, Paris $V^{e}$, or the Institut de l'Entente Universelle, Terres Rouges, Toulon, Var., the latter of which remains open during vacations.

Ar the British Commonwealth Education Conference which is being held at Bedford College, London, on July 24-30, under the presidency of Sir Percy Nunn, the general theme will be "Education in a Changing Empire". Native education in Africa and India occupies a considerable part of the programme of the proceedings of the Conference. The education of the non-European in Africa will be considered by the Rev. R. C. Blumer, Dr. G. G. Gillie, Miss Sara Burstall, Dr. S. Rivers-Smith, Mrs. Macgregor Ross, Mr. J. H. Driberg, and Mr. F. S. Livie-Noble. Education in India will be dealt with, under the chairmanship of Sir Phillip Hartog, by A. Yusif Ali, Fakhruddin Ahmad, and others, and the problem of bilingualism in Indian schools will be considered by Dr. Michael West. The Right Hon. W. Ormsby Gore, M.P., will give an address on "Some Education Problems of the Tropical Dependencies". Considerable attention, too, will be directed to interracial understanding, which is all to the good, showing how alive educationists are to this serious problem. Mr. H. Chaning Pearce and Miss A. Purvis will give addresses on the problem, and a discussion will be introduced by Mr. Arnold Iloyd. This subject will be closed by an address by Prof. H. J. Fleure. Among other subjects to be considered are vocational guidance, university problems in Africa south of Zambezi (Sir Carruthers Beattie), rural science and schools (Sir John Russell and others), the physical noeds of children from 2 to 7 (Dr. James Kerr), growth (Prof. A. H. Harris), an Imperial Film Institute (Dr. T. Drummond Shiels, M.P., Mr. G. T. Hankin, Mr. J. R. Orr, and Prof. J. L. Myres) and modern psychology. Demonstrations of new aids to education include one by the British Broadcasting Corporation. Sir Percy Nunn will consider the question of an Imperial Institute for Education. 